\title{
A Social Marketing Approach to a Social Brand. Findings and Implications from a Social Service of a Developing Economy
}

\author{
Dr. SYED ALI RAZA HAMID \\ Assistant Professor, Hamdard University, Islamabad, Pakistan \\ Email: alirazahamid@gmail.com \\ Ph: +92345-5550841 \\ Dr. FAROOQ AHMAD \\ Assistant Professor, SZABIST Larkana Campus Pakistan \\ FAISAL MASUD \\ Assistant Professor, Hamdard University, Islamabad, Pakistan
}

\begin{abstract}
Social brands are meant to address the most pervasive issues faced by consumers. Such issues relate to consumers' wellbeing and their relationship with the society. In developed countries, social brands are already playing a vital role in addressing issues prevalent in the society which have deep-rooted effects on consumers' wellbeing. Although the role of social services in developing countries is significant, it needs to be explored further, so that such services may create an identity among the consumers in order to be a social brand. As a prerequisite, the various dynamics of the consumer-society relation and the social concerns therein should be studied through some interactive research approach. In this regard, social marketing is a key strategy adopted by service organizations to gear themselves towards effecting social change and sustainable change in behavior. In developing countries, social issues are ubiquitous, being pervasive because of the incapacity of governments to respond cogently. In such scenario, private social services which do exist have considerable social impact and are seen to create a sense of affiliation among the stakeholders involved; which is characteristically similar to the phenomenon of brand-identification. Exploring the phenomenon of branding in social services, this research used grounded theory approach to unveil the process of a social brand. The main source of data was focus group discussions conducted with the stakeholders of a social service. The focus groups were the recipient and beneficiaries of a social service. Their experience with the social services tend to bring about a finding if a social service can be regarded as a social brand. The findings of the study indicate that given a service platform, the social services' agenda is implemented through stakeholders' shared participation, interaction, and engagement encapsulating value co-creation as social brand phenomenon. Value co-creation help social services develop trust, commitment, deliverance and relationships, factors considered vital for a social brand. The study contributed to social marketing theory by introducing eight key factors which represent social services activities and processes that lead them to be a social brand.
\end{abstract}

Keywords: Social Marketing, Social branding, Value Co-creation, Social Service, Grounded Theory.

\section{Introduction}

The idea of branding social services has been inadequately addressed in social marketing. Though branding has a central role in conventional marketing, its role in social marketing has yet to be seen. Social services' 
branding may be advanced by and large, by using social marketing in addition to conventional marketing. This will fairly advance the concept of social marketing and its practices which have barely come to fruition to meet the core objectives of social marketing on the one hand and to bring efficacy to practices of social marketing in social services setting on the other. The study underscores this issue by taking into account the practices of a social service organization as baseline data to aid social marketing to develop its own tools and techniques.

In order to see the process that how a social service becomes a social brand, the interaction with the stakeholders of a social service is assumed to be significant which is practically established through the association of people with the service (Ranjan \& Read, 2016). This social interaction has emerged to be a quite attention seeking phenomenon in the realm of services that involves reciprocal and shared acts of people. The phenomenon may bring about fruitful results for further progression of the field of marketing in terms of meaningful advances and transformation in long term business and social relationships. Such advances embody experiences and actions of the stakeholders which are meaningful transformational actors particularly for a service business. Due to such experiential activities, marketing has skewed towards service orientation with the idea of value creation rooted in exchange of acts. Such basis have been provided under dominant logic in terms of integrating tangible resources with intangible resources through stakeholders' activities Vargo et al. (2017).

The study aimed to explore the applicability of social marketing to social service branding as a part of social marketing strategy that may help marketers find the process for social services branding. In marketing literature, research on branding explicitly discusses that consumer values and socio-cultural contexts are vital to understanding consumer centric perspective which are socially constructed (Pappu, Quester, and Cookse, 2006). Using focus group discussion in social service context might introduce the process of social service branding and simultaneously identify the factors for social services branding. Generally social services by incorporating certain methods of social marketing have shown a significant amount of potential to effectively address social causes in terms of refining gross behavior (Hastings, 2007). Social marketing has been quite instrumental to reinforcing social pioneering initiatives of beneficiaries at community level (Bryant et al., 2014). The literature has some support for such social marketing campaigns which focused on conceptualizing and exploring the value creating phenomenon eventually moving towards social brands (Chapleo, 2015; Stride \& Lee, 2007; Underwood, Bond, \& Baer, 2001).

Generally branding in both for-profit and non-profit organizations has been the cornerstone in the twenty first century that helped them differentiate from one another (Berry, 2000). The process of social branding has barely been studied. By exploring the process the research has attempted to answer the questions such as how social services transform into brands and why do they become social brands? Moreover, what is the importance of social brands in a dynamic economy? The study also progressed in knowing the grounds which help stakeholders of social services differentiate between social services. In nutshell, the study explored the factors that help social marketers to transform social services into social brands. While exploring the process, the concept of social marketing became crystallized for better conceptualization of its implementation and control in a social brand's context (Degnegaard, 2014). There are multifarious actions taken by the stakeholders of social services which social marketing tend to address in terms of strategy. Social marketers' connivance towards such actions belong to supporting donors while performing donation related activities with regard to social causes. As a result of that, the growth of donors has not only substantially increased but also there has been an explicit change in beneficiaries' involvement and feedback. The Charity Aid Foundation (2013) offered a quite holistic view about the growth of donors and it is expected that the domain of donations is likely to increase to $\$ 233$ bn by 2030. Such an increase in donations is based on the actions of general public that they get reinforced and amounts to bring about strong behavior change. The other sources of donations have also increased due to such activities of organizations and groups which tend to co-create value amounting to (21\%) followed by the membership fees (17\%) (Charity Commission, 2013). Thus donors are increasingly 
vital stakeholders which spend time, effort, and money and make difference among other stakeholders. The study finds that emphasizing on the activities of stakeholders i.e. donors and beneficiaries and facilitating them by enhancing their communication skills and designing fundraising tactics for them may be proved quite instrumental. Such efforts as social marketing strategy may increase the level of confidence of the stakeholders and reinforce them to co-create value (Stride \& Lee, 2007).

However, it may be observed from such actions of stakeholders of social services that yet the gross behavior of public towards addressing social causes is dismal (Dann, 2010). Despite the efforts being made by some good social brands for creating social good among the society members, people have yet to structure their actions in light of social marketing. This requires social marketing to focus on such areas which might promote a voluntary behavior to bring about positive change in society. Social marketing as value driver may see improvement in social issues due to aggregate engagement and interaction of the members reflected through their behavior. Hence, a framework is required which could possibly be established using social marketing to see the efforts that align the activities of people with the social causes in society. Social marketing has proved to be quite an effective strategy to aptly address social issues (Andreasen, 1995).

\section{Literature Review}

Branding of social services needs to be researched more for conceptualization (Spotswood, 2011). The reason being multiple stakeholders exist for social services and their activities are not observed in relation to their association with social service - albeit evaluating brand building is dependent on perceptions, ideas and beliefs of service beneficiaries (Cayla \& Arnould, 2008). Concepts and ideas for branding or service branding may not be directly applied on branding of social services due to the fact that social service segments' expectations are somewhat different from conventional consumers (Irwin \& Baron, 2001; Barone, Norman \& Miyazaki, 2007).

On the contrary, it is however, desirable that social service brands should be examined as one, collective entity - because consumers experience social services as a 'complete package' and, therefore, require a more holistic and analytical approach. In research, there are various methods to explore the experiences of people in relation to branding of social services, however, grounded theory approach has been selected in the present study to explore the phenomenon of branding in social services. Classifying qualities and characteristics that are synonymous with a social service brand will better provide directions to the stakeholders of social services how to strategically adapt and furnish their experiential services in a befitting manner that refines the process of branding in social services (Brakus, Schmitt \& Zarantonello, 2009).

Spotswood (2011) has emphasized the need for exploration of branding in social marketing in relation to cultural mores and understanding consumers preferences through their experiences and firms' marketing activities (Andreasen, 2002). Similarly Schroeder (2009, p. 124) highlights the importance of branding in social context by exploring brands in relation to cultures: “...if brands exist as cultural, ideological, and sociological objects, then understanding brands requires tools developed to understand culture, ideology, and society, in conjunction with more typical branding concepts, such as brand equity, strategy, and value". This study contended to conceptualize from baseline the branding of social services as a need for creating a meaningful link between the cause and people actions that tend to associate with the service. Social brands are built on a deep understanding of how beneficiaries experience it in a given context. This further tends to build brand equity for the social service sector (Keller, 1993), and brings novelty and growth for the field of social marketing. This approach has been adopted to avoid a typical managerial and functional view that marketing scholars adopt on branding issues (Cayla \& Arnould, 2008). Moreover, this study has been conducted considering group dynamics approach pioneered and developed by by Kurt Lewin. The premise for keeping this approach proved be to be an antecedant that may create an integration among various resourses (Azmat et al., 2015). It is, however, believed that the participation of stakeholders will allow the study to produce an organic outcome about how social services are actually perceived as brands 
by people. Furthermore, while undergoing the process of assessing social brands, emotions, meanings and feelings of social services' stakeholders are likely to surface (Park \& MacInnis, 2006).

Branding in marketing has gained attention of many marketing scholars because it reflects deep reflections of consumers' emotions and feelings associated with product or service. Therefore, in academic research particularly, there is a strategic importance of branding and its effectiveness. It is important to study tangible and intangible assets being used by the stakeholders of social services that draw their interests and trust (Berry, 2000). Notwithstanding the fact that branding in marketing has critical role in establishing long term relations of customers with the product or service, however, the concept of branding in social services has scarcely been witnessed (Samad, 2010). The extant researches have accentuated to identify the factors that help social services become enduring social brand.

\section{Research Propositions}

P1: Participatory and interactive orientation (Beneficiaries' experience, engagement and interaction) positively reinforce social brand awareness.

P2: Relational orientation of service stakeholders is reinforced as a result of intangible resources.

\section{Methods}

This research used mixed method and primarily grounded theory approach to examine the process, and the contents that transform social services into a meaningful and strong brand (Boddy, 2016; Glaser \& Strauss, 1999; Mahrer, 1988). Furthermore, the research aimed to identify to what extent stakeholders in this process support in creating value by using ingredients to transform stream of value activities into a brand. This way an effective and useful theory or framework of social marketing might be developed for branding of social services. This research inquiry could have been appropriately examined empirically while exploring the phenomenon. The research design entailed early literature review followed by identifying a social service that revealed actions which are participative, interactive and interpretive. This process attempted to generate a relatively generalized case for social marketing using the platform of a social service (Eisenhardt \& Graebner, 2007).

The data collection was conducted in a manner to comprehend the phenomenon of branding in social services that further tended to explore various dimensions of research (Ghauri, 2004). Stake (2006) explained that such kind of inquiry may be better entertained by selecting a case through which that phenomenon could be assessed. Pauwels and Matthyssens (2004) also supported this approach to reach a generalizable outcome. This helped to produce the outcomes related to the actions of people which are proposed for branding of social services (Miles \& Huberman, 1994; Yin, 2009).

The study considered stakeholders of a social service which perform certain services for a given amount of time period and develop their association with the social service. The stakeholders of the social service were the unit of analysis who were supposed to provide the insights about their experience with the social service. Purposive sampling method was used which facilitated the data contextualization enriching the research method (Collis \& Hussey, 2014). Corbin and Strauss (1990) identified the reasons for opting for purposive sampling in this sort of research study which helps to produce an in-depth inquiry for building a theory. A case selection for in-depth information indeed directed to explore the phenomenon under research (Shah \& Corley, 2006). The source of information in the study was semi-structured in-depth focus group discussions which were conducted with the stakeholders of a social service. Four focus groups comprising five participants in each focus group as social service's stakeholders participated in focus group discussion. The dataset was compiled ensuring equal participants in four focus groups i.e. one manager, three beneficiaries and one donor. All participants of focus groups had reasonable amount of understanding about the matters pertaining to the social service. 
Discussion lasted for about 90 minutes with all focus groups, recorded and transcribed verbatim subsequently. Analysis included techniques such as qualitative coding comprising open, axial and selective coding (Miles and Huberman, 1994). Besides, constant comparative method was used. The techniques helped to uncover the factors that were considered to be the part of process that unravels social brand (Mackey \& Gass, 2011).

\section{Qualitative Data Analysis (Study 1)}

Shaukat Khanum is a social service organization which provides health services in the country. The organization is known for its quality health care with special focus on impoverished segments of society. The organization primarily relies on donations and other marketing campaigns which aim to raise awareness about the importance of donations. These campaigns partially intend to reflect strategies which are market focused. Hence, organization's activities in the study were explored with a view to assess the phenomenon of social brand process. The premise of social brand process comprised interactive, participatory and relational orientation of stakeholders. In order to analyze such stakeholders' orientation, a thematic analysis was conducted. Constant comparison method was used to support and develop themes on the basis of focus group discussion. Thematic analysis methodically explained the nature of activities performed by the stakeholders. Furthermore, data categorization, theme identification and aggregate theoretical dimensions were conducted to develop an insight of the process (Braun \& Clarke, 2013).

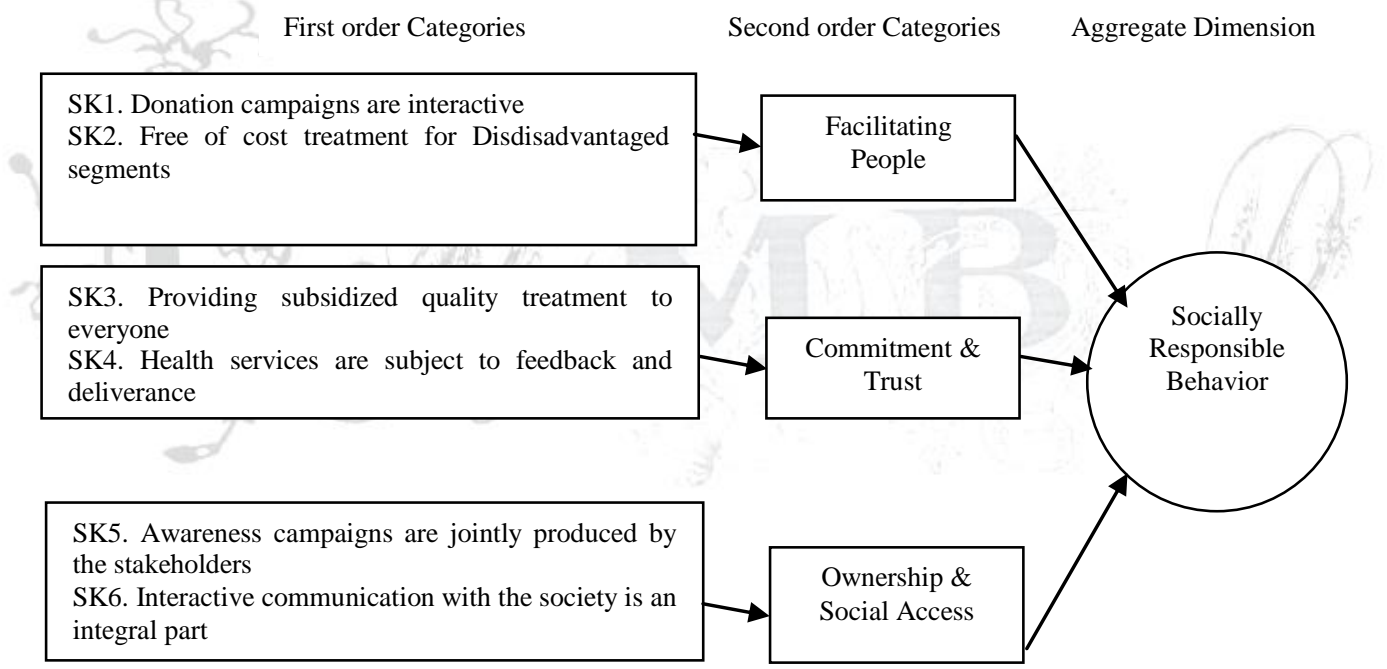

Fig 1 Socially Responsible Behavior Thematic Coding

Source: Developed by the Author using Comparative Contrast Method

Social, functional and emotional aspects of the activities of stakeholders were interpreted. These aspects are considered to be instrumental to interpret a responsible behavior (Crilly et al. 2008). Activities reflected through interactions, participation and engagement manifested some social, functional and emotional implications. Orchestrating participants' responses and their shared insights propose some meanings for responsible behavior. The stakeholders of the social service appeared to possess high perceived value that reinforced as a result of interactive process. Converging three aspects of the social service interpreted as socially responsible behavior. Valor and Carrero (2014) proposed such activities as socially consumed acts which he termed as determinant of socially responsible behavior. The study suggests socially responsible behavior to be a promising part of the social brand process in the ambit of social services. Stakeholders' behavior revealed characteristics which have association with shared values and shared responsibility to be strengthened as socially responsible behavior. (Han \& Stoel, 2016). 


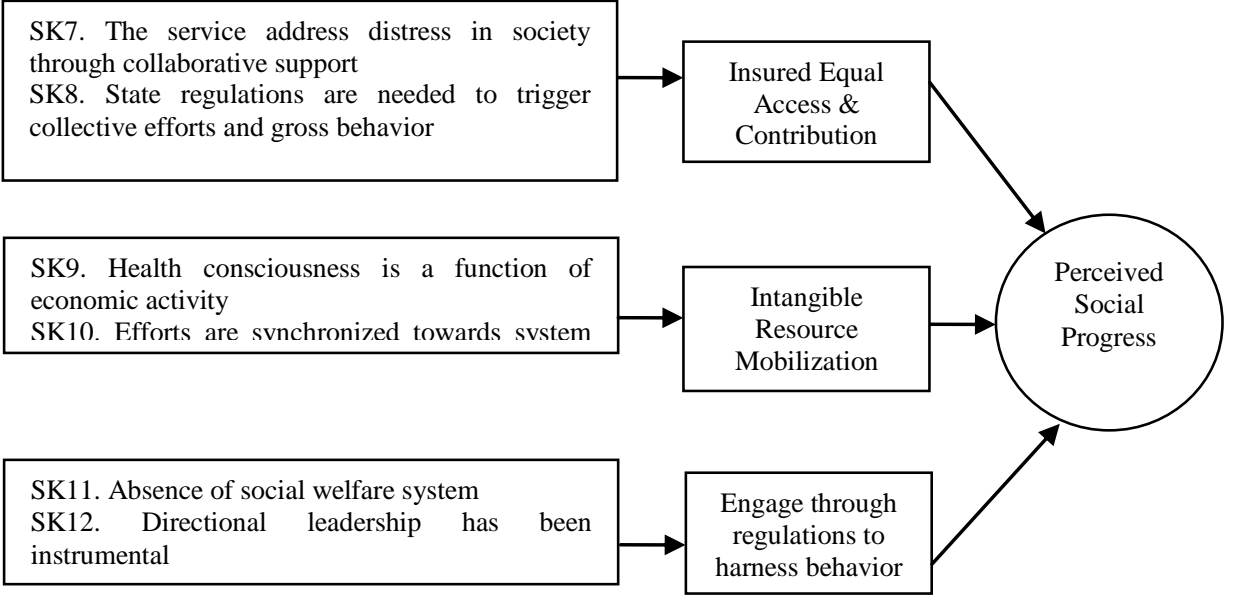

Fig 2 Perceived Social Progress Thematic Coding

Source: Developed by the Author using Comparative Contrast Method

Focus group discussion produced outcomes such as freedom of beneficiaries' action on the platform of the social service, self-recognition, and shared values as second order theme. The service facilitated the actions of its stakeholders by establishing online portals where the stakeholders freely and independently process their information related issues in their capacity. This shows the act of strengthening stakeholders' joint decision making with the management and gives them a sense of belongingness. The participants of focus group discussion explained these experiences as increased selfreliance and selflessness promoting shared values for social progress.

Marketing literature refers social progress as shared contribution of all stakeholders of a service adding to social wellbeing of society (Lefebvre, 2012). The study relates it to a social marketing strategy aiming to improve gross behavior of communities. The study further proposes and empirically justified in line with literature Perceived Social Progress as a key determinant of social brand in social marketing (Heinonen et al. 2013).

$$
\text { First order Categories Second order Categories Aggregate Dimension }
$$

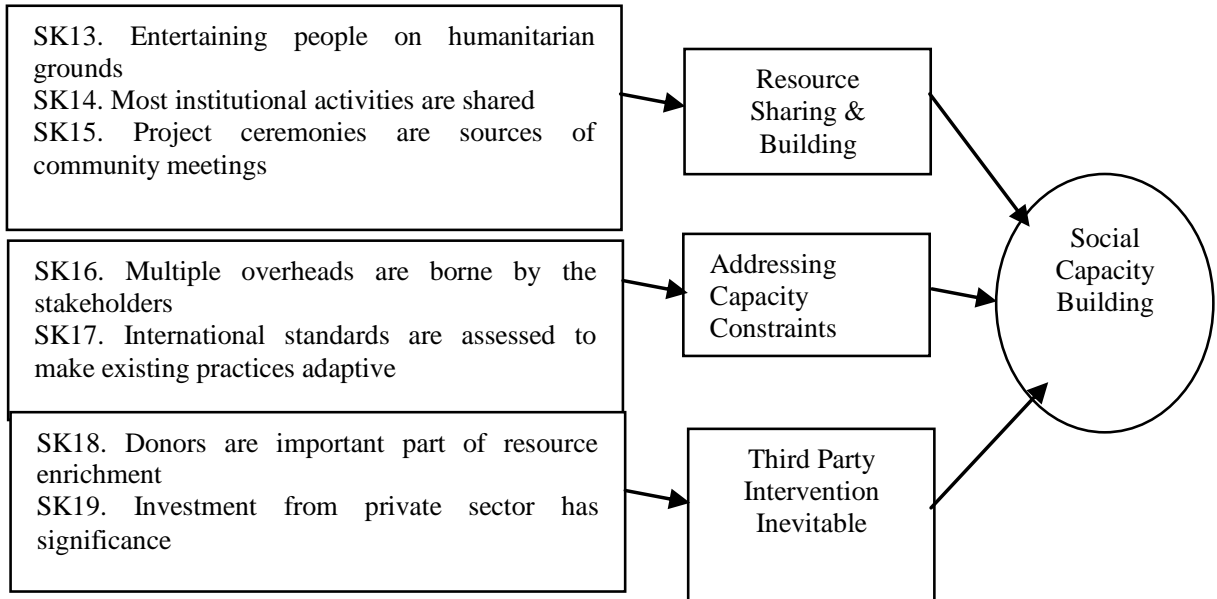

Fig 3 Social Capacity Building Thematic Coding

Source: Developed by the Author using Comparative Contrast Method 
The participants had a view that they have meaningful exchanges produced due to collaboration between the social service and its stakeholders. The discussion produced some ideas appeared as second order themes such as Resource Sharing and Building, addressing capacity constraint, and intervention through Outreach Programs. These themes are much synonymous with the research proposition of the study. Social Capacity Building has surfaced as a relevant and appropriate factor for social marketing. The factor of social capacity building reinforced due to resourcefulness that social service's beneficiaries value and experience. It was further expressed by the participants in relation to shared information and interventions that that they developed due to participation which in turn increased the probability of knowledge and learning capacities. Shared resources are likely to increase capacity building of service beneficiaries and also increase their association with the cause (Merino et al. 2012). Social services may pinpoint the issues faced by the stakeholders in light of the framework of capacity building and propose solutions using social marketing (De Vita \& Fleming, 2001).

First order Categories

Second order Categories Aggregate Dimension

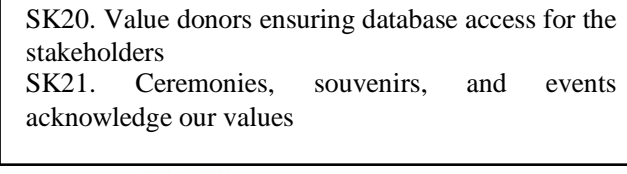

SK22. Information system and beneficiary database
are sources of service relationship
SK23. There is a sense of equity and equality
SK24. Follow up contacts are integral part
$\begin{aligned} & \text { SK25. Beneficiaries maintain their own databases } \\ & \text { ensured through updated technology }\end{aligned}$
Fig 4 Social Service Experience Themaic Coding

Source: Developed by the Author using Comparative Contrast Method

The responses illustrated personal experiences of the participants which marketing literature has referred to as Customer Experience. This construct has been highlighted by marketing scholars in relation to service and product (Homburg et al. 2015). Customer experience is based on experiential, interactive and relational activities of stakeholders of the service (Holbrook, 2006).

Though in marketing context, the construct has drawn the attention of scholars and practitioners alike but it needs a succinct explanation in relation to social marketing. Homburg, Jozic, and Kuehnl (2015) defined it in terms of people joint actions and engagements. It has been further operationalized while utilizing the service and developing social recognition, replication, social referrals, and social learning (Padgett \& Allen, 1997).

The participants of focus group discussion credited some factors important for service progression. These factors have been identified as knowledge sharing, sense of connectivity and equality, perceived access and perceived participation that increases tendency of engagement of the stakeholders. These factors as drawn by the participants of focus group are practically associated with emotions for products or services (Spinelli et al., 2014). 


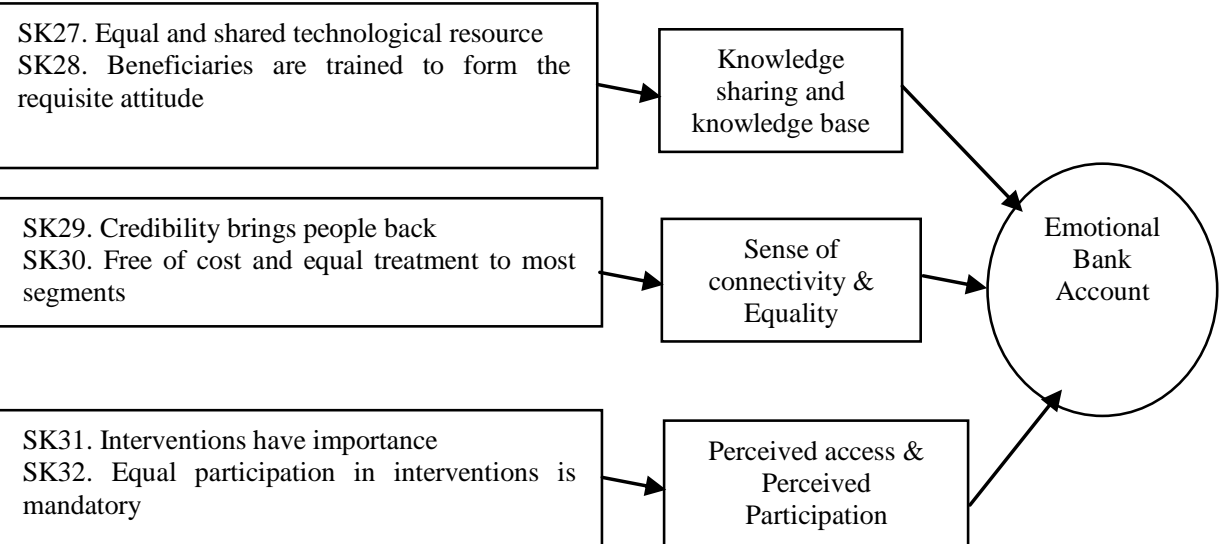

Fig 5 Emotional Bank Account Thematic Coding

Source: Developed by the Author using Comparative Contrast Method

These factors emerged due to interaction process on behalf of the social services (Meiselman, 2013). In marketing literature, brand love has appeared to be symbolically related to customers'emotional attachment with the product (Carroll \& Ahuvia, 2006). The basis for brand love were found to be related to experiences that customers have association with products and which they develop as part of their perceived expectations. Some intangible resources are knowledge, skill, motivation and confidence building enhance their liking and feelings for the service (Ranjan \& Read, 2016). Cases show such attributes as influential and explicit which decrease customers' dissatisfaction (Batra, Ahuvia, \& Bagozzi, 2012).

In entirety, these factors have produced positive emotions of people with the service (Kozinets, 2014). In relation to social marketing, these factors altogether formulate Emotional bank account on behalf of the stakeholders.

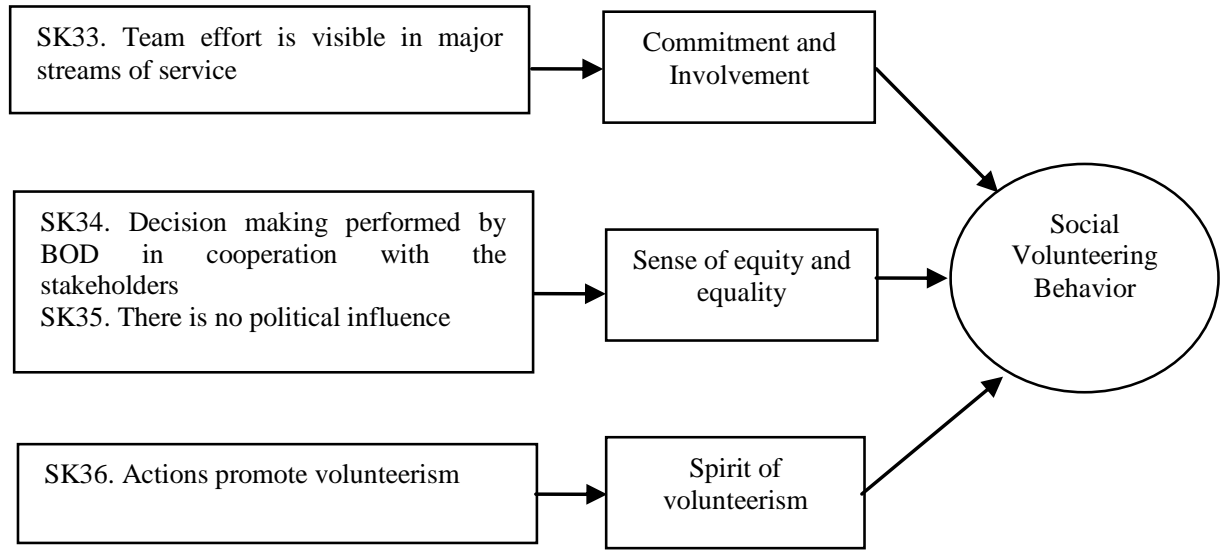

Fig 6 Social Volunteering Behavior Thematic Coding Source: Developed by the Author using Comparative Contrast Method

The primary goal of social services is to form pro-social behavior which might work even on voluntary basis. The participants of focus group discussion pointed out their enduring commitment in 
executing health service deliverables. The service encouraged participation of the stakeholders to determine voluntary participation (Lestari, Kakina, \& Kakinaka, 2015). Reasons identified by the participants are identical in marketing concept that emphasize value to be created identifying needs. Such needs ought to be explored by the stakeholders of the service. The participants viewed equity and equality being exhibited at the platform of the social service, commitment and involvement being shown by the beneficiaries of the service, and spirit of volunteerism as necessary to develop social volunteering behavior.

First order Categories $\quad$ Second order Categories Aggregate Dimension

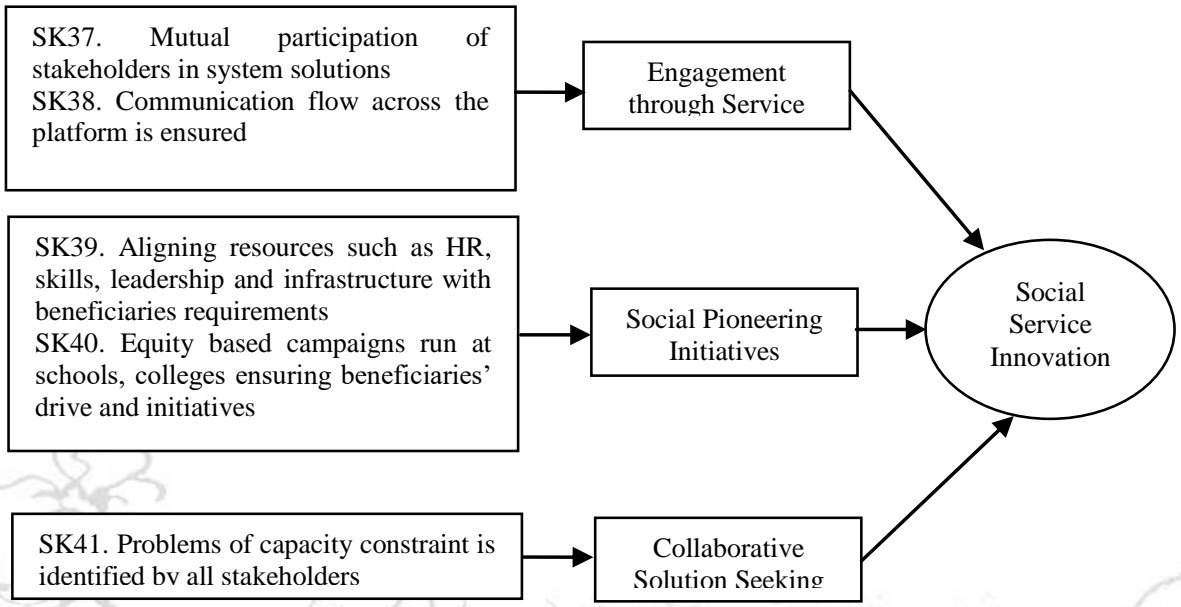

Fig 7 Social Service Innovation Thematic Coding

Source: Developed by the Author using Comparative Contrast Method

Risks are inherent features of businesses. Nonprofit organizations are also exposed to risks which tend to increase or decrease their performance. Social services are likely to minimize potential risks due to participation in community programs (Rexhepi et al. 2013). As the engagement level of social service's stakeholders is increased, social brands are more likely to innovate (Jeremy, 2016). The focus group discussion highlighted the fact that the stakeholders of the social service as a result of communication produced solutions that are productive in nature. This strategy may prove the social service as a social brand when social change is likely to be experienced by allowing initiatives to be taken by stakeholders. Moreover, the stakeholders propose solutions to the service which act as an agent of social change and encourage social innovation. These collaborative acts engaging stakeholders in the process create solutions for social issues and act as vital sources of innovation (Barkley, Cross \& Major, 2005).

Institution theory supports the concept that individual and group actions are dependent on their respective norms and values which in turn derive innovation among groups. The theory also enlightens the process of social pioneering initiatives (social innovation) that backs social change aligned with the culture of communities (Cajaiba-Santana, 2014). Communication has been accredited as one of the most important aspects that adds value to the framework of value co-creation in social services. Communication among groups occurs as a result of collaborations, and relational activities. The participants of focus group discussion ascribe shared nature of communication as extremely valuable which helps stakeholders maintain quality relationships between each other and with service (Ballantyne \& Varey, 2006). In the literature of marketing, communication is moderately dependent on collaborations, relations and engagements of service beneficiaries thus the scholars have referred it to as Collaborative Communication (Meek et al. 2011). 


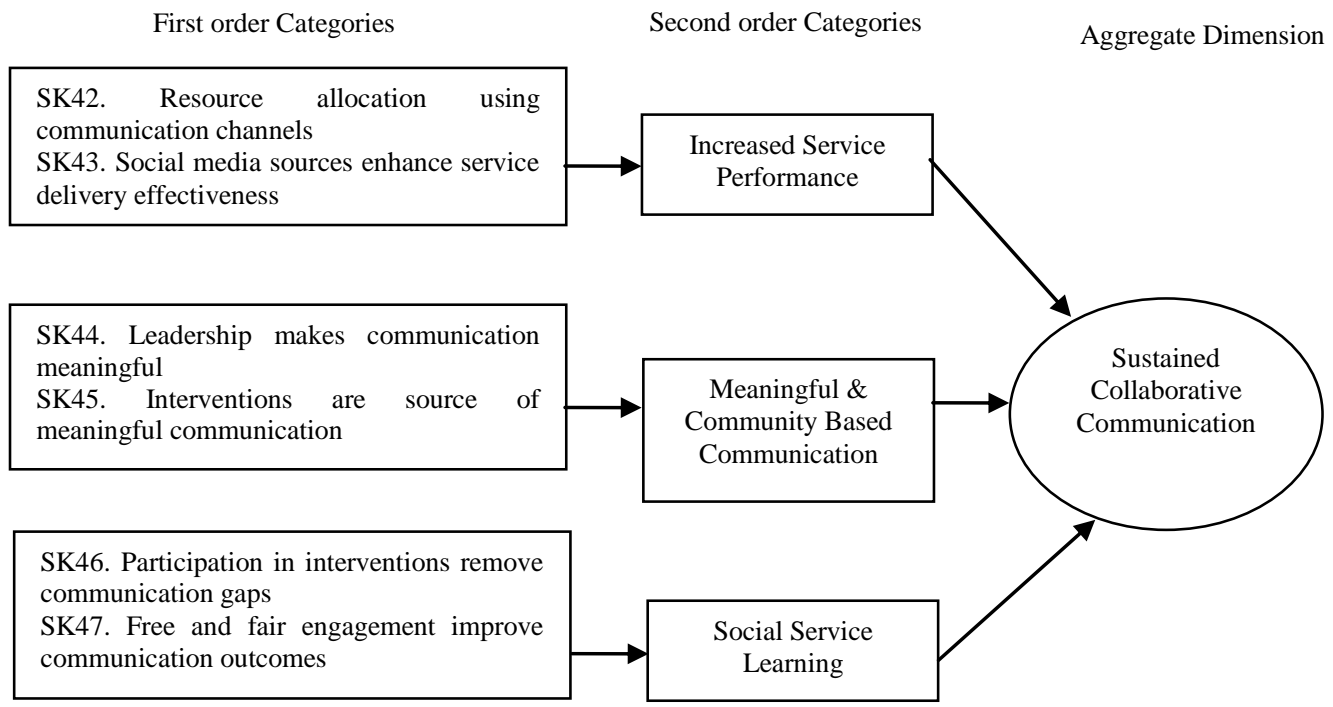

Fig 8 Sustained Collaborative Communication Thematic Coding Source: Developed by the Author using Comparative Contrast Method

The literature designates collaborative communication as a source of knowledge sharing which enhance groups' organizational learning process (Hajro, Gibson, \& Pudellko, 2017). Amount of trust shown by the stakeholders and their commitment towards the cause of service are credited as the most accepted consequences of collaborative communication. Collaborative communication occurs in the presence of high tendency of information sharing due to steady interactions of stakeholders (Ballantyne \& Varey, 2006). People with free and fair interaction also feel a sense of equality and equity and less social prejudice which further creates sustained collaborative communication.

\section{Quantitative Data Analysis (Study 2).}

\section{Introduction}

This section comprises sample characteristics, research instrument and analysis. A pilot study was conducted in this section. Exploratory factor analysis was used to evaluate the factors.

\section{Sample and Data Collection}

The data was collected in this section using convenience sampling. The respondents were briefed and engaged about the purpose of research. They were encouraged to provide independent feedback that represented their fair observation. The research was done in three sections comprising a period of two and a half months.

The first section involved administering the instrument to twenty five people. Here the aim was to assess the reliability of the items.

The second section involved distributing the instrument to three hundred respondents.

The third section entailed distribution of instrument to fifty respondents in order to validate the instrument. All three sections of study 2 aimed to ensure the efficacy of construct value co-creation (Yi \& Gong, 2013). 
Table 1Descriptive Statistics

\begin{tabular}{|llr|}
$\begin{array}{l}\text { Demographics } \\
\text { Percent }\end{array}$ & Frequency \\
Occupation & Student & 87 \\
23.2 & Job holder & 243 \\
64.8 & Business & 16 \\
4.3 & Retired & 16 \\
4.3 & Self-employed & 13 \\
3.5 & $20-30$ & 97 \\
Age & $31-40$ & 186 \\
25.9 & $41-50$ & 76 \\
49.6 & $51-60$ & 14 \\
20.3 & $61-70$ & 2 \\
3.7 & Intermediate & 13 \\
0.5 & Bachelors & 128 \\
Education & Masters & 211 \\
3.5 & MS/PhD & 23 \\
34.1 & Male & 162 \\
56.3 & Female & \\
6.1 & & \\
Gender & & 213 \\
56.8 & & \\
43.2 & & \\
& & \\
\hline
\end{tabular}

\section{Construct Reliability}

Construct reliability was established on the basis of the items of the scale to further perform internal consistency of the scale (Hair Jr. et al., 2006). The research followed the process of scale development of Churchill's (1979) and De Vellis (2012).

Reliability of the items is represented by Cronbach's alpha given in the table 6.2. Overall, the values of Cronbach alpha in the present case were between 50 and 65 indicating relatively low estimates of the measures but as there is no universal rule available for the minimum acceptable score criteria. Thus with reference to social science context such scores have relative proven acceptability (Bonett \& Wright, 2014). 
Table 2 Cronbach alpha Social Service Experience

\section{Items}

Item-to-total correlation

People generally want to help others in solving their problems

It has been observed that people are in search of good organizations

which are engaged in community service

People are satisfied with such organizations which take part in social

Services

Organizations with trained staff would not perform better social services

People use social media to get access to social services

Government and institutional support to organizations performing social

services ensure change in behavior

While following government regulations, it becomes difficult for

organizations to bring about social change

\section{Source: The Author}

Table 3 Cronbach alpha Perceived Social Progress

\section{Items social problems \\ Cronbach's alpha}

It becomes difficult for people to cooperate with organizations that give social services without the support of government

People engage in social service when they are empowered to participate in the organization's decision making

It has been observed that educational and vocational institutes have a role in increasing people's awareness about their basic social rights Organizations which believe in group work tend to give solutions to

\section{Item-to-total correlation}

\section{Source: The Author}

Table 4 Cronbach alpha Social Capacity Building

\begin{tabular}{|lc|}
\hline Items & Item-to-total correlation \\
When there is government and institution support, social services & .55 \\
When people use their time rightly, they bring about social change & .54 \\
People do not use their competence to bring about social change & .58 \\
Social events are a source of relationship building & .59 \\
Social events promoting social issues do not enhance the effectiveness & .48 \\
of social service & .47 \\
Social events are a source of resource wastage & .55 \\
Social events are a source of brotherhood & .59 \\
Communication becomes meaningful when people are kept informed & .53 \\
It has been observed that organizations with weak infrastructure deliver & .50 \\
social service & \\
A social service is not effective when it depends on donations and & \\
resources of people & .57 \\
Cronbach's alpha & \\
\hline
\end{tabular}

Source: The Author 
Table 5 Cronbach alpha Social Service Innovation

$\begin{array}{lc}\text { Items } & \text { Item-to-total correlation } \\ \text { Shared information is considered to be a source of solution for social problems. } & .50 \\ \text { Shared responsibility among people improves the social problems } & .45 \\ \text { It has been observed that organizations manage to seek solutions when they } & .49 \\ \text { mutually work with their stakeholders } & .62 \\ \begin{array}{l}\text { It has been observed that people have unfavorable attitude towards the } \\ \text { organizations that believe in change process }\end{array} & .50 \\ \text { It has been observed that organizations which involve people in their processes } \\ \text { are successful } \\ \text { Cronbach's alpha }\end{array}$

Source: The Author

Table 6 Cronbach alpha Social Volunteering Behavior

Items
$\begin{aligned} & \text { Making visits to localities under their charge does not help social } \\ & \text { service to perform better } \\ & \text { Being open and transparent is important for social service to be } \\ & \text { accepted by people } \\ & \text { It has been observed that there are more volunteers for organizations } \\ & \text { which allow people to participate in their decision making } \\ & \text { It has been observed that engaging people in workshops and training } \\ & \text { sessions bring about social change } \\ & \text { Cronbach's alpha }\end{aligned}$

Source: The Author

Table 8 Cronbach alpha Socially Responsible Behavior

$\begin{array}{|lc|}\text { Items } & \text { Item-to-total correlation } \\ \text { It has been observed that people devote time and efforts to eliminate social problems. } & .61 \\ \text { An organization offering social service with focused policies is perceived to be effective. } & .59 \\ \text { It has been observed that organization with weak procedures cannot offer social service } & .58 \\ \text { Social problems such as poverty can be reduced if people cooperate with each other } & .59 \\ \text { Most health services in country follow ethical practices } & .60 \\ \text { Responsible behavior originates from one's personality and values } & .60 \\ \text { It has been observed that people show responsible behavior when } & .61 \\ \text { there are more regulations } & \mathbf{. 6 1} \\ \text { Cronbach's alpha } & \end{array}$

Source: The Author 
Table 9 Cronbach alpha Emotional Bank Account

\begin{tabular}{|lc|}
\multicolumn{1}{c}{ Items } & Item-to-total correlation \\
while they participate in social work & .48 \\
People find social service to be functional when it is nearby physically & .36 \\
It has been observed that organizations which fail to address social & .39 \\
issues are considered trustworthy & .41 \\
It has been observed that organizations which use social media have & .38 \\
progressive social service & .42 \\
A social service's use of online sources has no effect on its credibility & \\
Success in addressing a social issue does not necessarily mean that & .38 \\
more people will engage with the service & $\mathbf{. 6 3}$ \\
People are dissatisfied with organizations doing more social work & \\
Cronbach's alpha &
\end{tabular}

Source: The Author

Table 10 Summary of the factors after reliability and factor analysis

\begin{tabular}{|lcc|}
\hline Factors/Variables & No of Items & Cronbach's Alpha \\
\hline Social Service Experience (SSE) & 7 & $\mathbf{0 . 6 1}$ \\
Perceived Social Progress (PSP) & $\mathbf{4}$ & $\mathbf{0 . 5 3}$ \\
Social Capacity Building (SCB) & $\mathbf{1 0}$ & $\mathbf{0 . 5 7}$ \\
Social Service Innovation (SSI) & $\mathbf{5}$ & $\mathbf{0 . 5 9}$ \\
Social Volunteering Behavior (SVB) & 4 & $\mathbf{0 . 6 2}$ \\
Social Collaborative Communication (SCC) & $\mathbf{5}$ & $\mathbf{0 . 6 5}$ \\
Socially Responsible Behavior (SRB) & 7 & $\mathbf{0 . 5 3}$ \\
Emotional Bank Account (EBA) & 7 & $\mathbf{0 . 6 3}$ \\
\hline
\end{tabular}

Source: The Author

Construct Validity - Exploratory Factor Analysis. Construct validity was determined using exploratory factor analysis. Maximum likelihood method employed as a measure of the dimensions of variables. This was performed in SPSS 20. Items with low loading below .4 were deleted. The standard deviation of the items was also tested causing deletion of the items with low scores. This helped finalize the instrument.

Table 11 Factors Correlation

\begin{tabular}{|c|c|c|c|c|c|c|c|c|}
\hline Variable & SSE & PSP & SCP & SSI & SVB & $\mathrm{SCC}$ & SRB & EBA \\
\hline SSE & 1.00 & & & & & & & \\
\hline PSP & 0.45 & 1.00 & & & & & & \\
\hline SCP & 0.15 & 0.19 & 1.00 & & & & & \\
\hline SSI & 0.17 & 0.18 & 0.06 & 1.00 & & & & \\
\hline SVB & 0.32 & 0.24 & 0.13 & 0.32 & 1.00 & & & \\
\hline SCC & 0.27 & 0.19 & 0.19 & 0.20 & 0.10 & 1.00 & & \\
\hline SRB & 0.05 & 0.02 & 0.08 & 0.17 & 0.05 & 0.08 & 1.0 & \\
\hline EBA & 0.14 & 0.07 & 0.12 & 0.11 & 0.32 & 0.06 & 0.00 & 1.00 \\
\hline
\end{tabular}

PROMAX Rotation and Deleted Items. In exploratory factor analysis, promax factor rotation is performed to evaluate factor loadings that identify the variables to be finally included in study. The analysis suggested that factor loading of 0.3 or 0.4 be removed and 0.5 be considered aptly significant (Hair et al., 2010). Thus, items with 0.4 were finally deleted. Bartlett's Test of Sphericity and Kaiser-Meyer-Olkin (KMO) were used to have the suitability of data as well as goodness of fit of the data. Significance level of the test i.e. $(\mathrm{P}<0.05)$ indicated correlation between the variables. Chi- square value of 8279.666 in Bartlett's test of 
sphericity with p value of 0.000 . KMO measured adequacy of sample. KMO produced the value of 0.732 indicating an adequacy of sample in factor analysis.

\section{Results of KMO}

Table $12 \mathrm{KMO}$ and Bartlett's Results

\begin{tabular}{|lcc|}
\hline \multicolumn{3}{|c|}{ KMO and Bartlett's Test } \\
\hline Kaiser-Meyer-Olkin Measure of Sampling Adequacy & \multicolumn{1}{c|}{} \\
& Approx. Chi- Square & $\mathbf{8 2 7 9 . 6 6 6}$ \\
Bartlett's Test of Sphericity & df & $\mathbf{3 2 4 0}$ \\
& Sig. & $\mathbf{. 0 0 0}$ \\
\hline
\end{tabular}

Source: The Author

The dataset was finally evaluated conducting Bartlett's Test of Sphericity and the Kaiser-Meyer-Olkin (KMO). Bartlett's Test of Sphericity was significant at $\chi^{2}=8279(\mathrm{p}<0.000, d f=3240)$. KMO produced a value of 0.732 (Hair et al., 2010).

\section{Discussion}

This study aimed to analyze how social marketing approaches in social services organizations specifically devise social brands. The significant contribution of this study is developing a phenomenon of social branding on the basis of interaction and experience that stakeholders of the service encounter. Branding has been the core construct in marketing so far but its social relevance and implications have hardly been addressed. Some notable authors have emphasized the importance of social brands and the way such brands are managed and experienced (Naidoo \& Abratt, 2017). Moreover, the prominent feature of the study is that it has employed a mixed method approach using both qualitative and quantitative methods. The qualitative method aimed to gain the ground reality that social brands experience while the quantitative method empirically verified the insights which were obtained in the early part of study. These two methods sought stakeholders involvement and their relevant experiences which occur while interacting on the platform of social services (Lemon \& Verhoef, 2016). These two parts of study unraveled an insight that the main dynamic is stakeholders' knowledge and skills that emerge as part of social marketing strategy and help social services to be a social brand (Baron et al., 2014).

The study viewed group dynamics as a premise for social marketing that my produce a platform of system having dynamism for creating value for all the stakeholders. The group dynamic approach is most suitable for generating interventions which are likely to generate an environment where the stakeholders collectively propose meaning to the service (Saunders \& Truong, 2019).

\section{Conclusion}

The study aimed to investigate social marketing approaches that social services employ and create viable solutions for the problems that social services are supposed to grapple. In order to explore the phenomenon of social brand by understanding the process, the study adopted a grounded theory approach which aimed to grasp the insights through data emanating from the given platform. The study unveiled factors which are instrumental to the process of social brand development. A few proposed propositions based on literature provided directions to accomplish the study in a gratifying manner. The study produced key theoretical and practical findings which indicate that social services employing social marketing facilitate a process that help social services become a social brand. Moreover, such process proves to be a dynamic orientation for the stakeholders of a social service. Social marketing as an indispensable and non-fabricated marketing approach may increase their credibility and credential for social branding. Collective participation and engagement of the stakeholders tend to develop sense of association, sense of 
ownership and social identity which are instrumental to give sustainable solutions for social issues. Moreover, through interactive communication social credibility and resourcefulness are likely to emerge which provide intangible assets to social services.

\section{Reference}

Andreasen, A. R. (2002). Marketing Social Marketing in the Social Change Marketplace. Journal of Public Policy \& Marketing, 21(1), 3-13.

Andreasen, A.R. (1995), Marketing Social Change: Changing Behaviour to Promote Health, Social Development, and the Environment, San Francisco: Jossey Bass.

Azmat, F., Ferdous, A.S., Couchman, P. (2015). Understanding the dynamics between social entrepreneurship and inclusive growth in subsistence marketplace. Journal of Public Policy \& Marketing. Vol. 34 (2).

Ballantyne, D., \& Varey, R. J. (2006). Introducing a dialogical orientation to the service- dominant logic of marketing. In Robert F. Lusch, \& Stephen L. Vargo (Eds.), The service-dominant logic of marketing: Dialog, debate and directions. New York: M.E Sharpe.

Barkley, E. F., Cross, K. P. \& Major, C. H. (2005). Collaborative Learning Techniques. NewYork: JosseyBass Higher and Adult Education.

Baron. A. T. Norman, Miyazaki, A.D. (2007). "Consumer Response to Retailer Use of Cause- Related Marketing: Is More Fit Better?”Journal of Retailing, 83 (4).

Baron, S., Warnaby, G., Hunter-Jones, P. (2014). Service(s) Marketing Research: Development and Directions. International Journal of Management Reviews. Vol. 16.

Batra, R., Ahuvia, A., \& Bagozzi, R. P. (2012). Brand love. Journal of Marketing, 76.

Berry, L. L. (2000). Cultivating service brand equity. Journal of the Academy of Marketing Science, 28(1): $128-137$.

Birks, M., \& Mills, J. (2011). Grounded theory: A practical guide. Los Angeles, CA: Sage.

Boddy, C.R. (2016),"Sample size for qualitative research", Qualitative Market Research: An International Journal, Vol. 19 No.4

Bonoma, T. V. (1985). Case research in marketing: Opportunities problems, and a process. Journal of Marketing Research, XXII, 199-208.

Brakus, J.J., Schmitt, B.H., Zarantonello, L. (2009). "Brand Experience: What Is It? How Is It Measured? Does It Affect Loyalty?”Journal of Marketing, Vol. 73, No. 3

Braun, V., Clarke, V., (2013), Successful Qualitative Research: A Practical guide for Beginners. London : Sage.

Bryant, C. A., Courtney, A. H., McDermott, R. J., Lindenberger, J. H., Swanson, M. A., Mayer, A. B.,.Biroscak, B. J. (2014). Community-based prevention marketing for policy development: A new planning framework for coalitions. Social Marketing Quarterly, 20(4).

Cajaiba-Santana, G. (2014), "Social innovation: Moving the field forward. A conceptual framework", Technological Forecasting \& Social Change, 82.

Carrol, B.A., Ahuvia, A.C. (2006), "Some Antecedents and Outcomes of Brand Love", Marketing Letters, 17 (2)

Cayla, J., \& Arnould, E. J. (2008). A Cultural Approach to Branding in the Global Marketplace. Journal of International Marketing, 16(4), 86-112. doi: 10.1509/jimk.16.4.86

Chapleo, C. (2015). Brand 'infrastructure' in nonprofit organizations: Challenges to successful brand building? Journal of Marketing Communications, 21(3), 199-209. doi: 10.1080/13527266.2012.741609

Charity Commission. (2013). Available at:http://www.charitycommission.gov.uk/aboutcharities/sectorfacts-and-figures/ [Accessed 10 March 2016].

Collis, J., \& Hussey, R. (2014). Business Research: a practical guide for undergraduate and postgraduate students. Fourth Edition, Palgrave Macmillan.

Corbin, J., \& Strauss, A. (1990). Grounded Theory Research: Procedures, Canons and Evaluative Criteria. Zeitschriftf\&\#xfc;r Soziologie, 19(6), 418-427. 
Churchill, G. A. (1979). A paradigm for developing better measures of marketing constructs. Journal of Marketing Research, 16(1), 64-73.

Crilly, D., Schnieder, S.C., Zollo, M.., (2008). Psychological Anticedents to Socially Responsible Behavior. European Management Review. 5

Dann, S. (2010). Redefining social marketing with contemporary marketing definitions. Journal of Business Research, 63

Degnegaard, R. (2014). Co-creation, prevailing streams and a future design trajectory. 10:2, 96- 111, DOI: 10.1080/15710882.2014.903282

DeVellis, R.F. (2012), "Scale development: theory and applications", Applied Social Research Methods Series, Sage Publications, London.

De Vita, C.J., Fleming, C. (2001), “Building Capacity in Nonprofit Organizations”, The Urban Institute.

Eisenhardt, K.M., Graebner, M.E., (2007), Theory building from cases: Opportunities and challenges. Academy of Management Journal. Vol. 50, No. 1

Glaser, B., \& Strauss, A. (1999). The Discovery of Grounded Theory: Strategiesfor Qualitative Research: Aldine Transaction.

Hair, J.F., Black, W.C., Babin, B.J. \& Anderson, R.E. (2010) Multivariate data Analysis: A global perspective (7th ed.). New Jersey, NJ: Pearson Education Inc.

Hair Jr., J. F. Black., W.C. Babib., B.J., Anderson, R.E., \& Tatham, R.L.,(2006), Multivariate data analysis $\left(6^{\text {th }}\right.$ ed). Upper Saddle River, New Jersey: Pearson Prentice Hall.

Hajro, A., Gibson, C.B., Pudelko, M., (2017), Knowledge exchange processes in multicultural teams: Linking organizational diversity climates to teams' effectiveness. Academy of Management Journal, Vol. 60, No. 1

Han, Tae-Im., Stoel, L. (2016), "Explaining Socially Responsible Consumer Behavior: A Meta-Analytic Review of Theory of Planned Behavior", Journal of International Consumer Marketing DOI: 10.1080/08961530.2016.1251870

Hastings, G., 2007. Social Marketing: or, Why Should the Devil Have All the Best Tunes. Butterworth-Heineman, London.

Heinonen, K., Strandvik, T., Voima, P., (2013), “Customer dominant value formation in service”, European Business Review Vol. 25 No. 2.

Holbrook, M.B. (2006), "Consumption experience, customer value, and subjective personal introspection: an illustrative photographic essay", Journal of Business Research, Vol. 59 No. 12

Homburg, C., Jozic, D., Kuehnl, C., (2015). Customer experience management: toward implementing an evolving marketing concept $J$. of the Acad. Mark. Sci. DOI 10.1007/s11747-015-0460-7

Irwin, J. R., Baron, J. (2001). "Response Mode Effects and Moral Values," Organizational Behavior and Human Decision Processes, 84 (2).

Jeremy, T. (2016), "Rethinking brand innovation from the inside out", Journal of Brand Strategy, Vol. 5, No. 2.

Keller, K. L. (1993). Conceptualizing, Measuring, Managing Customer-Based Brand Equity. Journal of Marketing, 57(1), 1-22.

Kozinets, R.V. (2014). Social Brand Engagement: A New Idea. Engagement. Vol.6, No.2.

Lefebvre, R.C. (2012) Transformative social marketing: co-creating the social marketing discipline and brand. Journal of Social Marketing, 2 (2).

Lemon, K.N., Verhoef, P.C. (2016). "Understanding customer experience throughout the customer journey”, Journal of Marketing, Vol. 80 No. 6

Lestari, S., Kotani, K., Kakinaka, M., (2015). Enhancing voluntary participation in community collaborative forest management: A case of Central Java, Indonesia. Journal of Environmental Management. 150

Mackey, A. Gass, S.M. (2011), Research Methods in Second Language Acquisition: A Practical Guide. Oxford: Blackwell.

Mahrer, A. R. (1988). Discovery-oriented psychotherapy research: Rationale, aims, and methods. American Psychologist, 43(9), 694-702. doi: 10.1037/0003-066X.43.9.694

Meek, W. R., Davis-Sramek, B., Baucus, M. S., \& Germain, R. N. (2011). Commitment in franchising: The role of collaborative communication and a franchisee's propensity to leave. Entrepreneurship Theory 
and Practice, 35(3)

Meiselman, H. L. (2013). The future in sensory/consumer research: Evolving to a better science. Food Quality and Preference, 27.

Merino, S. S., Carmenado, I., \& de los, R. (2012). Capacity building in development projects. Procedia Social and Behavioral Sciences, 46, 960-967.

http://dx.doi.org/10.1016/j.sbspro.2012.05.231

Miles, \& Huberman. (1994). Qualitative Data Analysis: An expended sourcebook.

Naidoo, C., Abratt, R. (2017). Brands that do good: insight into social brand equity. Journal of Brand Management. Vol. 25. No.1

Padgett, D., Allen, D. (1997). Communicating experiences: A narrative approach to creating service brand image. Journal of Advertising. Vol. 26, No. 4.

Pappu, R., Quester, P. G., \& Cooksey, R. W. (2006). Consumer-based brand equity and country-oforigin relationships. European Journal of Marketing, 40(5/6), 696-717. doi: http://dx.doi.org/10.1108/03090560610657903

Park, C. MacInnis, D. (2006), "What's In and What's Out: Questions over the Boundaries of the Attitude Construct,"Journal of Consumer Research, 33 (1)

Patton, M. Q. (1990). Qualitative evaluation and research methods. Newbury Park: Sage.

Pauwels, P., \& Matthyssens, P. (2004). The Architecture of Multiple Case Study Research in International Business. In Rebecca Marschan-Piekkari, \& Catherine Welch (Eds).

Handbook of qualitative research methods for international business. Cheltenham: Edward Elgar.

Ranjan, K.R., Read, S., (2016), "Value Co-creation: Concept and Measurement", J. of the Acad. Mark. Sci.44.

Rexhepi, G., Kurtishi, S. and Bexheti, G. (2013), "Corporate social responsibility (CSR) and innovation -The drivers of business growth?", Procedia: Social and Behavioral Sciences, Vol. 75

Samad, N, (2010), "Branding in Contraceptive Social Marketing: The Pakistani Experience." Social Marketing Quarterly June 2010 vol. 16 no. 2 50-68

Saunders, S., \& Truong,V. (2019). Social marketing interventions: insights from a system dynamics simulation model. Journal of Social Marketing. Vol. 9, No. 3.

Schroeder, J. E. (2009). The cultural codes of branding. Marketing Theory, 9(1), 123-126. doi: $10.1177 / 1470593108100067$

Shah, S. K., \& Corley, K. G. (2006). Building Better Theory by Bridging the Quantitative-Qualitative Divide*. Journal of Management Studies, 43(8), 1821-1835. doi:10.1111/j.14676486.2006.00662.x

Silverman, D. (2011). Interpreting qualitative data. Sage.

Spinelli, S., Masi, C., Dinnella, C., Zoboli, G. P., \& Monteleone, E. (2014). How does it make you feel? A new approach to measuring emotions in food product experience. Food Quality and Preference, 37

Spotswood, F. a. T., A. . (2011). Brand co-creation for effective social marketing: the "lose the fags" case study. In: The 2nd World Non-Profit and Social Marketing Conference, Dublin, Ireland, 11-12 April 2011. Available from: http://eprints.uwe.ac.uk/13922.

Stake, R. E. (2006). Multiple Csae study Analysis. New York: The Guilford Press.

Stride, H., \& Lee, S. (2007). No Logo? No Way. Branding in the Non-Profit Sector. Journal of Marketing Management, 23(1/2), 107-122.

Underwood, R., Bond, E., \& Baer, R. (2001). Building Service Brands via Social Identity: Lessons from the Sports Marketplace. Journal of Marketing Theory and Practice, 9(1), 1-13. doi: 10.1080/10696679.2001.11501881

Valor, C., Carrero, I. (2014), "Viewing Responsible Consumption as a Personal Project", Psychology \&Marketing, Vol. 31, No. 12

Vargo, S.L., Koskela-Huotari, K., Baron, S., et al. (2017) 'A systems perspective on markets- toward a research agenda', Journal of Business Research 79

Yi, Y., Gong, T. (2013). Customer value co-creation behavior: Scale development and validation. Journal of Business Research. 66.

Yin, R. K. (1994). Case Study Reserach Design and Methods (2nd ed.). Thousand Oaks: Sage. 